ISSN $1014-4874$

DOI : http://dx.doi.org/10.4314/rj.v25i1.6

\title{
Land Tenure Security in Informal Settlements of Kigali City. Case study in Muhima Sector
}

Bizimana Jean Pierre ${ }^{1}$, Mugiraneza Theodomir ${ }^{2}$, Twarabamenye Emmanuel ${ }^{1}$ and Mukeshimana Marie Rose ${ }^{3}$

1 National University of Rwanda, Faculty of Science, Geography Department

2 National Universities of Rwanda, Centre for Geographic Information Systems and Remote Sensing

3 Rwanda Natural Resources Authority

\begin{abstract}
Rapid urbanization of Kigali City is a direct consequence of increasing development of informal settlements in the city. This research sought to identify challenges related to land tenure systems in informal settlements, analyze problems related to lack of land ownership, assess existing planning policies, and suggest alternatives for coping with highlighted problems using Muhima sector as a case study. Desk study was used for scrutinizing existing policy documents on urban development in Rwanda. Primary data were collected by field observation, households' survey by questionnaire and structured interview with local authorities. Cluster area sampling was used to determine sample cells and out of seven cells of Muhima Sector, three cells were randomly selected. Sample size was composed of 60 households picked up proportionally to the number of households in sampled cells. Findings revealed that majority (71\%) of households hold land in informal arrangements where land rights are not recognized in public land registry. Informal land market was a key characteristic in the sector as most of plots were acquired through informal purchase. Hence, land is not an instrument for economic development in the sector because it cannot be used as collateral in financial transactions. It was observed that $60 \%$ of respondents have never requested for bank loans because of lack of documents for land ownership, and land is given at low values during expropriation for urban redevelopment. Land is not properly demarcated and registered, and boundary conflicts are frequent, occurring at $35 \%$ of land conflicts in the sector. Due to distortion of land market, local authorities and landowners do not have common understanding in transferring de facto land rights through purchase and selling. There is a need to speed up land tenure regularization and formalization in urban informal settlements.
\end{abstract}

Key words: Kigali, informal settlements, land ownership, land tenure challenges 


\section{Introduction}

Tenure informality is a key characteristic in informal settlements and in many countries where private sector target is to develop land and housing for high- and middle-income groups, urban poor may have no option than living in informal settlement (Durand-Lasserve and Selod, 2007 p.3). Lack of security of tenure hinders most attempts to improve shelter conditions for the urban poor, undermines long-term planning, and distorts prices for land and services. It has a direct impact on access to basic urban services and on investment at settlement level, and reinforces poverty and social exclusion (Durand-Lasserve, 2006). Likewise, land tenure in informal settlements is informally held and does not provide enough security for its residents. Since these settlements are not part of the formal land management system, there is a lack of reliable information necessary for planning as well as for the formulation of policies and programmes for informal settlement upgrading and regularization (Paudyal, 2006; Paudyal and McDougal, 2010). Tenure informality worsens access to shelter and security of tenure (Lopez-Moreno, 2003) and ensuring security of land tenure through de facto protection against evictions or de jure land tenure regularization can have obvious benefits in terms of enhanced investment incentives, improvements in equity, and reduction of conflicts related to land, especially in urban areas in developing countries (Duland-Lasserve and Selod, 2007).

Rwanda, as all Sub-Saharan Africa countries, faces similar problems in urban planning. The main issue is how to deal with different forms of land tenure, especially the informal tenure, with respect to formal urban standards (Ilberg, 2008) Since its independence in 1962, Rwanda has been using the master plan approach as a tool for urban planning without providing the necessary land for housing (OZ Architecture, 2007). This approach has resulted in development of informal settlements due to multiple reasons, including lack of adequate implementation of urban planning standards, rapid urban growth, reform of urban boundaries, lack of proper urban land policies (Nsamba-Gayiiya, 2006). In Rwanda, urban land tenure is an issue that needs to be addressed urgently in all aspects, especially in Kigali City (Hajabakiga, 2004).

\section{Problem statement}

Due to rapid urbanization in Kigali City, the official land delivery channels have been unable to avail developable land at a rate matching the population growth. As a result, most people occupy public land without land ownership. Particularly in Muhima, informal settlements have been 
rapidly growing since 1994 when most of Rwandese who had fled both in 1959 and 1994 returned home. As Kigali City urbanized, informal settlements which used to be tolerated was no longer acceptable (Ilberg, 2008). The government tried to stop the informal settlements and slum areas development and get rid of existing ones by relocation and expropriation, linked to enforcement of building regulations in line with the implementation Kigali Conceptual Master Plan. The new urban planning policies are no longer accepting the use of low-cost construction materials such as mud bricks and wood (Kalimba and de Langen, 2007). Therefore, relocating informal settlement dwellers is being experienced for availing space for urban redevelopment.

Based on 2005 Organic Land Law, prompt, adequate, and effective compensation must be provided in case of expropriation for public interest. Government can only expropriate for a public purpose, on a nondiscrimination basis, and in accordance with due process of law (MINTERE, 2007). Even if expropriation has been going, the implementation processes of some expropriation projects have raised misunderstanding between the Kigali City council and the residents. One prominent case is the Ubumwe Cell Project located in Muhima Sector within Nyarugenge District. The expropriation of Ubumwe cell started in 2005, when Kigali City Council decided to embark on the urban redevelopment by removing informal settlements in the central part reserved for Central Business District (CBD). Families originally settled in the developable zone were relocated and resettled in outer ring of the city (Batsinda site) after compensation. Between July and December 2007, Kigali City Council carried out a valuation survey to determine the compensation value. First residents of Batsinda were relocated from Ubumwe Cell and expropriated before the official adoption of the new expropriation law. Families to be relocated did not agree on the offered compensation, and refused to move before settling what they considered as "unfair compensation". Later after, these households have been forced to leave their original dwelling area felt that they were not given enough hearing during valuation and compensation exercise (Kairaba, 2008). Drawing from Muhima case, this research aims at identifying challenges related to land tenure systems in informal settlements, analyzing problems related to land tenure security and suggesting alternatives for coping with highlighted challenges. 


\section{Theoretical framework}

Land tenure should primarily be viewed as a social relation involving a complex set of rules that govern land use and land ownership (DurandLasserve and Selod, 2007). More specific, land tenure is the perceived institutional arrangement of rules, principles, procedures and practices, whereby a society or community defines control over, access to, management of, exploitation of, and use of means of existence and production (Dekker, 2005). In many countries, absolute owner of all land is the state or head of state. The two common forms of tenure can be identified consecutively as freehold and leasehold. Freehold means that the owner can do what he or she likes with the land, subject to any restrictive covenants and the various planning regulations that are imposed by statute with regard to the use of the land. Freehold is absolute since the state retains the right to acquire land in the public interest. Leasehold means that freehold owner, who in some cases may be the state, has relinquished most of the rights in the land for a set of period of time such as 99 years during which the leasehold owner has the right to use land or property but at the end of which the title returns to the freehold owner (UN-ECE, 1996). In the context of Rwanda, land tenure may be considered as a set of modes or procedures of land acquisition and ownership. It is in other words, a combination of rules that define the modes of access, use and control of land and its renewable natural resources. It is therefore a relationship between men or social groups and land or its underlying resources (MINITERE, 2004).

A landholder has security of tenure if she/he perceives little or no likelihood of losing physical possession of the land in the future (Hanstad, 1998). The land tenure security refers to the degree of confidence held by people that they will not be arbitrarily deprived of the land rights enjoyed and/or of the economic benefits deriving from the land. Land law and policies should determine the level of tenure security. Land law includes both objective elements such as nature, content, duration and enforceability of the rights, state guarantee, quality of boundary descriptions, conflict handling; and subjective elements such landholders' perception of the security of their rights (Deininger, 2003; Kanji et al., 2005). Security of land tenure exist when individuals perceive that they have the right to a piece of land on a continuous basis, free from imposition or interference by outside sources, as well as the ability to reap the benefits of labour and capital invested in such land, either in use or upon transfer to another holder. In Kigali City, the land remains the exclusive property of the State. The right to use, develop and occupy the land is granted by the government under the permit to occupy regime. The State retains the eminent ownership 
of the land and is entitled to take it back if leaseholders of plots of land for housing in urban or suburban areas cannot develop the land within 5 years, according to construction standards set out by public authorities (DurandLasserve, 2007)

Frequently, there is a correlation between the lack of official recognition of dwellers by the authorities, and insecurity of tenure even if the informality does not automatically spell a lack of secure tenure. As such, secure tenure can exist without formal recognition by state authorities due to the fact that acceptance and acknowledgement by community institutions may in fact be valued more for fostering a feeling of tenure security among property owners, than the formal recognition through titles granted by the state (Kombe, 2005; McAuslan, 2001). It is widely acknowledged that for the urban poor, access to secure land and shelter is something of a precondition for attaining access to other benefits of urban life. Secure tenure is thus a necessary foundation for all endeavors to improve the living conditions of the urban poor (Payne, 2002).

The ownership means the right to enjoy the use of something, the ability to dispose of it and benefit from the rights associated with it. With real property, this is referred to as the title, which is the highest level of land rights. The title is held by the owner, who may not necessarily be possession of the land (UN-ECE, 1996). Land tenure reform in Rwanda is aiming at to give confidence through tenure security, enable registration of transactions in term of sale or rental, recognize intrinsic land value, but will mandate confiscation for non-productive use (Dyer, 2007).

The significance underlying the informality concept can also have various meanings. Terms like informal settlement, squatter settlement, spontaneous settlement, uncontrolled settlement, slum settlements and unauthorized, unplanned, self-generated, and marginal settlements are used interchangeably (Vuuren, 1997). The informality can have various causes: informality of land acquisition, illegality of subdivision and/or non conformity with land use planning and building regulation (van Asperen, 2007). The UN-Habitat (2004) broadly conceived the slums areas as one lacking in any of the following conditions: (a) access to adequate water supply; (b) access to adequate sanitation facilities; (c) sufficient living area; (d) structural quality/durability of dwellings; and (e) security of tenure.

The forced eviction and inadequate compensation are the most observed challenges related to land tenure system in urban informal settlements. Forced eviction is "the permanent or temporary removal against their will of individuals, families and/or communities from the homes and/or land which they occupy, without the provision of, and access to, appropriate 
forms of legal and other protection" (UN-Habitat, 2004). Some evictions are not forced in the strictest legal sense, but most of them are also disruptive causing the same destruction (UNESCAP and UN-Habitat, 2008). Whether the occupant is a tenant or the owner of his dwelling unit in informal settlements, evictions may take place if the occupant does not comply with an administrative or a court expropriation decision. In such cases, expropriated owners are entitled to receive compensation corresponding to the market value of their property as assessed by the administration and, in case of dispute, by a tribunal.

In case of urban redevelopment, informal settlements' residents are however in a different situation: their irregular situation regarding planning, development and/or construction norms (in the case of informal commercial land subdivisions) and, more importantly, their tenure status, means that they are not entitled to claim compensation for the replacement cost of their land and dwelling unit. They can be evicted with or without compensations or resettlements options. Evictions may follow formal/legal procedures but the empirical observations show that many evictions do not have full legal basis, or are not carried out according to legal procedures. The level of tenure security depends on evidence the occupants of any settlement can provide. Occupants in informal settlements do not usually have any real rights such as a property title or a lease. In many cases, other documents such as administrative permits, deeds of sale, receipts, invoices, ration cards, may be accepted as evidence of quasi-ownership, but with a lower value than real rights or leaseholds. This tenure status is more or less worse for residents in informal settlements especially during compensation while expropriation is taking place. Therefore, expropriation is most time considered as involuntary resettlement(Durand-Lasserve, 2007).

\section{Materials and methods}

Desk study was used for scrutinizing existing policy documents on urban informal development and in developing countries in general and particularly in Rwanda. These documents helped to acquire background information on problems related to land tenure resulting from rapid urbanization in urban informal settlement areas. Primary data were firstly collected by field observation, which helped to observe land tenure related problems on ground and to describe the study area. A households' survey by questionnaire and structured interview with local authorities have also been used to get more detailed information at household level. Cluster area sampling was used to determine sample cells. Out of seven cells of Muhima Sector, three cells located in western part of the sector were selected for questionnaire administration namely Amahoro, Kabeza and Nyabugogo. 
The eastern part of the Muhima Sector (Ubumwe and Rugenge cells) was excluded because a great part was already expropriated for urban redevelopment (Figure1: Map of the study area).

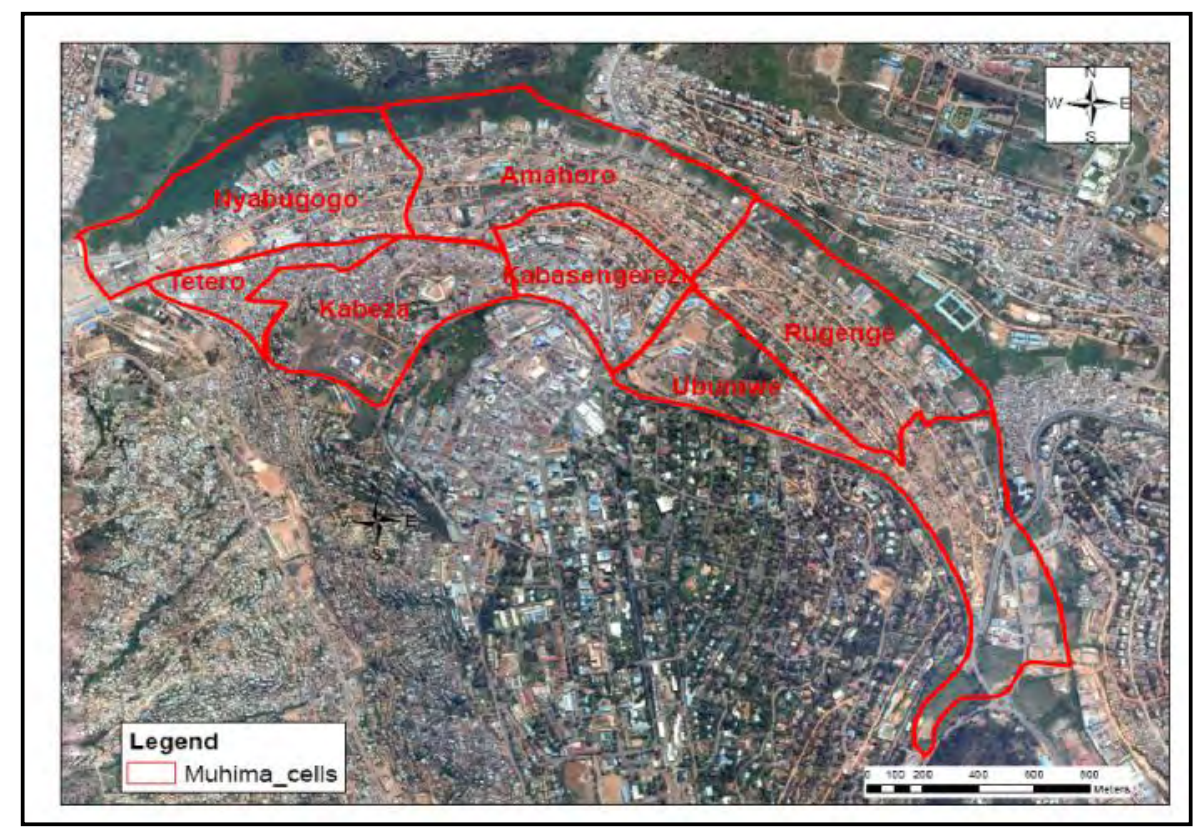

Figure 1: Map of the study area

Source: CGIS-NUR and National Institute of Statistics, 2006

Household was considered as our unit of analysis. Samples were picked up in respective cells within the same sector. The total households in study area were 2470 counting 40\% for Amahoro Cell, 32\% for Tetero cell and $28 \%$ for Nyabugogo cell. Sample size was composed of 60 households picked up proportionally to the number of households in sampled cells.

\section{Results and discussion}

Research findings revealed that a big number of households are holding land in informal arrangement. Table 1shows that $71 \%$ of respondents acquired their plots through purchase, 13\% through inheritance, $8 \%$ through gifts and $8 \%$ through other means. 
Table 1: Means of land acquisition in Muhima Informal Settlements

\begin{tabular}{|l|c|c|}
\hline Means & Number of respondents & Percentage (\%) \\
\hline Purchase & 17 & 71 \\
\hline Inheritance & 3 & 13 \\
\hline Gift & 2 & 8 \\
\hline Other means & 2 & 8 \\
\hline Total & 24 & 100 \\
\hline
\end{tabular}

Source: Field survey, September, 2009

Based on the table 1, it is clear that informal land market was a key characteristic in Muhima informal settlements where $71 \%$ of plots were acquired through informal purchase. This high percentage of informal lands acquisition explains the limited supply of affordable land for housing urban population by the city planning authorities in Kigali City. This situation is also confirmed by the high population density in Muhima informal settlements $\left(11,128\right.$ inhabitants per $\left.\mathrm{km}^{2}\right)$. Other means include for squatting on public land (Nyabugogo wetlands) and on private land especially after 1994 post-conflict and post-genocide period; and donation by public authorities.

Concerning land tenure security, land rights of the most respondents are not recognized in public land registry even if the article 7 of Organic Land Law protects equally the rights over the land acquired from custom and the rights acquired from written law. The majority of residents hold sale agreements as legal documents of their plots while others have only certificate of property ( $82 \%$ of respondents). This research also revealed that none of respondents had a freehold document which is normally recognized to provide full tenure security. People in such insecure tenure are facing the risk that their rights over land are being threatened by competing claims, and even lost as result of relocation after compensation. This was the case in informal settlements of Ubumwe Cell, Nyarugenge District while Kigali City planning authorities relocated households from irregular settlements to carry out infrastructure development and urban renewal projects where 336 households have been relocated and 123 among them were moved and settled in Batsinda site.

Like in other developing countries, the main causes of evictions in Kigali City are increasing urbanization; large urban infrastructure improvement projects to make cities more attractive to new investments; market forces where public land is increasingly being used for profitable rather than social purposes, city beautification to attract more investments and to market the city; and ineffective laws to protect communities from eviction 
or to provide them with tenure security. Even if some good laws do exist in developing cities, they are sometimes freely broken, because of the unequal power relationship between poor households and the governments and developers. In almost every way, evictions are the opposite of development and a major cause of poverty in several ways: (i) they move the poor from the city centre and push them into the unserviced peri-urban areas, away from their places of work; (ii) they put additional burdens of time and transport expenses on the poor; (iii) they distance the poor from health care and schools and increase the rich-poor divide in cities; (iii) they bring about the loss of investments in housing, infrastructure and small businesses, and the destruction of household goods; (iii) they destroy social support systems that existed in the old communities; (iii) they create situations of violence and trauma for some of most vulnerable groups; they produce new, under-serviced settlements that governments can ignore, far from the city centres (UNESCAP and UN-Habitat, 2008) .

The expropriation of Ubumwe Cell started in July 2005, when Kigali City Council decided to embark on expropriation process with the main aim of removing slums in the interest of the livelihoods of the slums dwellers. A site where to move families to be expropriated was identified in Batsinda in term of part of compensation. In July 2007, KCC started the expropriation process in Ubumwe Cell, Muhima Sector, Nyarugenge District. Between July and December 2007, KCC carried out valuation survey to determine the compensation value of the community to be expropriated. About 67 families of Ubumwe community did not agree to compensation offered, they refused to move until their issue of just compensation is settled. On $5^{\text {th }}$ August 2008, 67 families of Ubumwe Cell, that had refused to move out awaiting settlement of dispute over the just compensation, were forced to move out. According to KCC authorities, this community was becoming a security concern, and was delaying the KCC development plans. On the other hand, the forced community feels that, they were not given enough hearing and that the force used was not necessary (Kairaba, 2008).

However, the majority of respondents from Muhima Sector $(70 \%)$ suggested that regularization and upgrading of informal settlements may be alternative solutions to their problems of land ownership. In addition, it is very important to consider that access to land and security of tenure is one the conditions for urban sustainable development as adopted by Habitat II in 1996 in Istanbul Declaration: "providing legal security of tenure and equal access to land to all people, including those living in poverty... Ensuring transparent, comprehensive and accessible systems in 
transferring land rights and legal security of tenure..." (UN-Habitat, 1996). Although upgrading projects are envisaged in some areas of Kigali City, most are not intended to regularization because plots have not been developed according to required norms and standards, especially regarding the minimum legal plot size as shown in Figure 2.

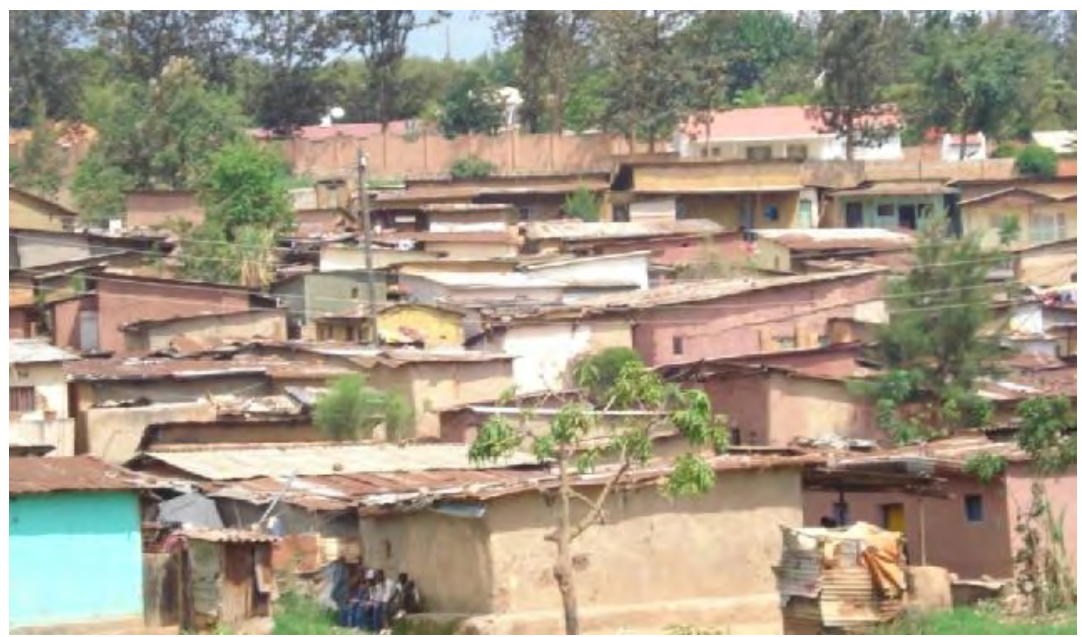

Figure 2: Informal settlement in Muhima Sector Source: Taken by Author in September 2009

The main objective of the Kigali City Council is rather to carry out urban renewal projects in order to make prime land in central and peri-central area available for development (City of Kigali, 2002). The land cleared in this manner is invariably used for high-income housing development. The scale at which forced eviction, relocation and compensation took place is some time limited, in reflection of the limited demand for new high-income housing.

In Muhima, land is not an instrument for economic development because it cannot be used as collateral to financial institutions. Indeed, $60 \%$ of respondents have not ever requested bank loans. Only $40 \%$ of respondents have requested loans from bank using houses and non constructed plots as collateral. This low level of bank loan request is due to the lack of ownership document. One of the main reasons of requesting the bank loan, the trading purpose dominates with $38 \%$ of respondents; $29 \%$ of respondents requested loan from bank for house construction, $12 \%$ of respondents for purchasing plots and $21 \%$ for other reasons (Table 2). 
Table 2: Reasons for requesting loan from bank

\begin{tabular}{|l|c|c|}
\hline Purpose & Number of respondents & Percentage \\
\hline Trading & 9 & 38 \\
\hline House construction & 7 & 29 \\
\hline Purchasing plot & 3 & 12 \\
\hline Other purpose & 5 & 21 \\
\hline Total & $\mathbf{2 4}$ & $\mathbf{1 0 0}$ \\
\hline
\end{tabular}

Source: Field survey, September, 2009

In absence of land ownership documents, other collateral types used to get loan from bank included monthly salary, house domestic devices, car, forming groups...etc.

Because of lacking evident for land ownership; land is given a low value during expropriation for urban redevelopment as $55 \%$ of respondents are not willing to be expropriated. Relocated slum residents have received some money in terms of compensation, but the value of land itself is not considered. Property valuation is based on a low value estimate by planning authorities. Furthermore, compensation is paid after long delays without taking into account price fluctuation. (Kalimba and de Langen, 2007). It often does not take into account the actual market value of land and alternative resettlement sites in sub-urban areas (Durand-Lasserve, 2007). Moreover, most of new identified sites for resettlement are located in peripheral zones far from the city centre; and they are considered as underserviced settlements that government can ignore as shown in the below (see Table 3).

Table 3: Reasons against relocation - expropriation

\begin{tabular}{|l|c|c|}
\hline Reason & Number of respondents & Percentage \\
\hline Affordable cost & 4 & 12 \\
\hline Is near the city centre & 14 & 42 \\
\hline No elsewhere to go & 8 & 24 \\
\hline Other reasons & 7 & 21 \\
\hline Total & $\mathbf{3 3}$ & $\mathbf{1 0 0}$ \\
\hline
\end{tabular}

Source: Field survey, September, 2009

As main reasons for staying and not willing to be relocated, $42 \%$ of respondents declared that Muhima settlement is located near the city centre, $24 \%$ have no place to go, $21 \%$ condemned unfair compensation and lack of required infrastructure in newly identified sites. Pertaining to alternative solutions to relocation-expropriation problems, $70 \%$ of respondents claimed for a just compensation if really relocation is the last option. They also suggested to resettle the evicted people and to upgrade existing informal settlements where it is possible (see Table 4). 
Table 4: Alternative solutions of relocation and expropriation

\begin{tabular}{|l|c|c|}
\hline Solution & Number of respondents & Percentage (\%) \\
\hline Resettle of evicted people & 9 & 15 \\
\hline $\begin{array}{l}\text { Upgrading of informal } \\
\text { settlements }\end{array}$ & 9 & 15 \\
\hline $\begin{array}{l}\text { Just compensation after } \\
\text { expropriation }\end{array}$ & 42 & 70 \\
\hline Total & $\mathbf{6 0}$ & $\mathbf{1 0 0}$ \\
\hline
\end{tabular}

Source: Field survey, September, 2009

Given that land is not properly demarcated and registered (lacking of information on plots' size; overlap between plots which shared the same boundaries), boundary conflicts are frequently occurring: $35 \%$ of land conflicts in surveyed households were reported. These related land conflicts occurred between their native families $(24 \%)$, with neighbors $(29 \%)$, with landlords and tenants (19\%) and with local authorities $(9 \%)$ in charge of land management and housing development.

Due to distortion of land market, local authorities and landowners are not having common understanding in transferring de facto land rights through purchase and selling. High income households are buying land from local populations to immediately construct houses. Almost the whole process of land transfer is being done by negotiation between land owners and land seekers and right over land is registered through private conveyancing. The cost is fixed trough bargaining and money is transferred hands by hands and sometimes without the consent of official authority and all other members of the family who have the rights to the land to be sold. This may lead to unfair land prices, social conflicts, loss of a considerable amount of state earning that should be gained from land transfer taxation. This informal land market is the response and people's initiative to a high demand of land for housing and the short supply in the context of rapid urbanization of Kigali City and lack of planning regulations for land markets and as well as the formal procedures of acquiring land that were always cumbersome and expensive.

\section{Conclusion and recommendations}

The aim of this research was to identify challenges related to land tenure systems in informal settlements in Kigali City and suggest alternatives for coping with highlighted problems using Muhima Sector as case study.

Findings show that most of residents in Muhima informal settlement do not have tenure security. The underpinning factors of uncertainty of tenure security are among others prevailing of customary land rights and inability 
to avail land for housing development through formal channel by urban housing and land management departments. Land rights transfer through selling/buying is concluded by private conveyancing where rights over land are not recorded in the formal land registry. Consequently, informal settlements dwellers are exposed to unwilling and unpredictable displacement. Majority of displaced poorest families is relocated to Batsinda, the new identified site at the edge of the city, while others have to find new dwelling by their own arrangements. Less level of tenure security of Muhima informal settlement is an impeding factor for economic opportunities, given that their property are not used as an economic instrument through bank loan and mortgage. Property long term investment seems to be risky. Land is given a low value during expropriation for urban redevelopment. While expropriation is recognized by public regulations, it is not well accepted by informal settlement residents especially in its content related to land compensation. Residents consider that their land is undervalued during compensation. Furthermore, compensation is paid after long delays without taking into account price fluctuation.

As residents in urban informal settlements are worried about expropriation and relocation, public authorities should explain residents on law governing expropriation and compensation. Compensation rates should be regularly readjusted. Additionally, residents in the re-developable areas should be informed earlier before relocating them. If urban renewal and redevelopment project have to promote social cohesion of the entire Kigali City, the ongoing urban redevelopment should also think about population aspirations in the areas to be expropriated.

\section{References}

1. City of Kigali. (2002) Kigali Economic Development Strategy, Final Report. http://www.grandslacs.net/doc/2692.pdf.

2. Deininger, K. (2003) Land Policies for Growth and Poverty Reduction. World Bank, Washington

3. Dekker, H.A.L. (2005) In pursuit of land tenure security, Amsterdam University Press.

4. Duland-Lasserve, A., and Selod, H. (2007) The formalization of land tenure in developing countries; World Bank's 2007 Urban Research Symposium ; Washington; 14-16 May 2007

5. Durand-Lasserve, A. (2006) Informal settlements and the Millennium Development Goals: global policy debates on property ownership and security of tenure. Global Urban Development Magazine 2(1), 1-15. 
6. -. (2007) Market-driven eviction processes in developing country cities: the cases of Kigali in Rwanda and Phnom Penh in Cambodia. Global Urban Development Magazine, 3(1), 1-14.

7. Durand-Lasserve, A., and Selod, H. (2007) The formalization of land tenure in developing countries; World Bank's 2007 Urban Research Symposium ; Washington; 14-16 May 2007

8. Dyer, R. (2007) Land issues in Rwanda drawn from DFID Technical Assistance for Land Tenure Reform 2005-08; Department for International Development (DFID) Rwanda; July 2007.

9. Hajabakiga, P. (2004) Addressing Land Issues in Post Conflict Setting: the Case of Rwanda; Market Asset or secure Livelihood Conference, London, 8- 9 November 2004.

10. Hanstad, T. (1998) Designing land registration systems for developing countries; American University International Law Review.

11. Ilberg, A. (2008) Beyond Paper Policies: Planning Practice in Kigali.http://www.n-aerus.net/web/sat/workshops/2008/Edinburgh/ papers/NAERUS_2008_Ilberg_.pdf

12. Kairaba, A. (2008) Expropriation process; Land Net Rwanda Chapter, Issue Paper No1/2008.

13. Kalimba, I., and de Langen, M. (2007) Infrastructure provision as part of Slum Upgrading: the case of Kigali, Rwanda; ENHR 2007 International Conference on Housing and Sustainable Urbanisation in Developing Countries; Rotterdam 2007.

14. Kanji, N., Cotula, L., Hilhorst, T., Toulmin, C., and Witten, W. (2005) Summary Report Can Land Registration Serve Poor and Marginalised Groups. Securing Land Rights in Africa, International Institute for Environment and Development (IIED).

15. Kombe, W.J. (2005) Land use dynamics in peri-urban areas and their implications on the urban growth and form: The case of Dar es Salaam, Tanzania. Habitat International, 24, 113-135.

16. Lopez-Moreno, E. (2003) Slums in the World: the Face of Urban Poverty in the New Millennium. Monitoring the Millennium Development Goals, Target 11- World-wide Slum Dwellers Estimations. The Global Urban Observatory, UN-Habitat. Nairobi.

17. McAuslan, P. (2001) Non-statutory Security of Tenure and Law: The Legality of Illegality and the Illegality of Legality. Paper presented at the "Tenure Project Workshop" hold in London, 16.-19 January 2001.

18. MINITERE. (2004) National Land Policy; Ministry of Lands, Environment, Forestry, water and Mines; Kigali. Rwanda. 
19. MINTERE. (2007) Organic Law relating to expropriation in the public interest; Law $\mathrm{N}^{\circ} 18 / 2007$ of 19/04/2007, Ministry of Lands, Environment, Forestry, water and Mines; Kigali. Rwanda.

20. Nsamba-Gayiiya, E. (2006) Towards Developing a Comprehensive Implementation framework of the Rwanda National Land Policy and Land Law: Contribution from LandNet Rwanda Chapter. http://www.oxfam.org.uk/What Accessed on 5th July 2009.

21. OZ Architecture. (2007) Kigali Conceptual Master Plan; Prepared for the Rwanda Ministry of Infrastructure.

22. Paudyal, D.R. (2006) Pro-poor Land Management System: A Study Considering Dynamic Aspect of Land Tenure in Nepal. XXIII FIG Congress. Munich, Germany.

23. Paudyal, D.R., and McDougal, K. (2010) Spatial Data Infrastructure for Pro-poor Land Management; FIG Congress 2010; Facing the Challenges - Building the Capacity Sydney, Australia, 11-16 April 2010.

24. Payne, G. (2002) Introduction. In G. Payne (ed.), Land, rights and innovation: Improving tenure security for the urban poor. London: ITDG Publishing.

25. UN-ECE. (1996) Land Administration Guidelines With Special Reference to countries in Transition, United Nations, New York and Geneva.

26. UN-Habitat. (1996) 'Adequate shelter for all" and "Sustainable human settlements development in an urbanizing world". United Nations Conference on Human Settlements (Habitat II), Istanbul; Turkey 3-14 June 1996.

27. -. (2004) Global campaign for secure tenure: A tool for advocating the provision of adequate shelter for the urban poor, Nairobi, Kenya

28. UNESCAP, and UN-Habitat. (2008) Quick Guides for Policy Makers on "Housing the Poor in Asian Cities"; The United Nations Human Settlements programme (UN-HABITAT) and the United Nations Economic and Social Commission for Asia and the Pacific (UNESCAP).

29. van Asperen, P.C.M. (2007) Effects of multiple land tenure regimes on tenure security: African cases; Second European Conference on African Studies, Leiden, 11-14 July 2007.

30. Vuuren, A.V. (1997) The strengths and problems of black families in informal settlements. Pretoria: Human Sciences Research Council. 